7B44

\title{
人工股関節周囲骨の術後力学適応シミュレーション
}

Computational study for bone remodeling after total hip replacement

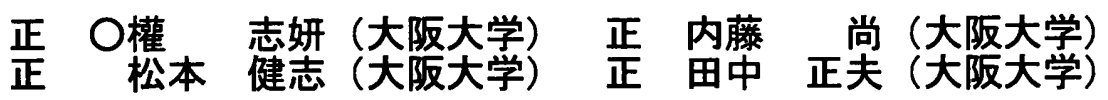

Jiyean KWON, Graduate School of Engineering Science, Osaka University, 1-3, Machikaneyama, Toyonaka, Osaka Hisashi NAITO, Takeshi MATSUMOTO, Masao TANAKA, Osaka University

Key words: bone remodeling, total hip replacement, stress shielding, mechanostat theory

\section{1. 粕吾}

人工股関節手術は, 股関節の障害の治療としての関節可動 域の改善に有効である。しかしながら，人工関節を長期間利 用することで，磨耗，緩み，人工関節や骨セメントの破損な どが発生することが報告されている(e.g.1).このような問題は， 大腿骨頭部の切除ならびにステム挿入により, 大腿構造が変 化し, 荷重伝達の様相が変わることによって生ずると考えら れる，さらに，金属製のステムと生体骨では材料特性が著し く異なるため人工関節と生体骨の境界部分で stress shielding が発生し易く，これが周囲の骨組織に影響を与え，緩みの原 因となる，骨の適切な位固に荷重を伝え骨組織の stress shielding を防ぐために，生体骨と人工関節の幾何学的適合性 に着目して置換術計画を立案する手法が提案されている (2),(3). しかし，骨は力学㻴境の影響を強く受け，骨細胞がそ の刺激に反応し，骨芽細胞及ひ破骨細胞活動のバランスによ り骨量が維持されることが知られている. そのため, 長期の 適合性評価には骨リモデリングを考虑する必要がある.

本稿では，骨の人工関節界面での力学環境の変化により生 ずる骨形状の変化の様子についての骨リモデリングシミュ レーションによる予測結果について検討する.

\section{2. 方法}

個体別モデルとして，CT 画像を用いて骨形状を基に骨お よびステムの 3 次元有限要素モデルを作成し，そのモデルを 用いて，骨基質に生しるひずみを力学刺激として想定したメ カノスタット理論(4)に基づいた骨リモデリング数理モデルに より，骨りモデリングシミュレーションを行う。

\section{2-1. 胃リモデリング数理モデル}

ひずみの大きさにより，生理的ひずみ範囲(Physiological Window, PW)，低ひずみ範囲(Disuse Window，DW)，および 高ひずみ範囲(Overuse Window，OW)において，それぞれに 応じて骨形態変化を支配するメカニズムを考えた ${ }^{(5)}$.

相当ひずみが $\varepsilon_{p l}<\varepsilon<\varepsilon_{p u}$ である PW では骨梁表面りモデリ ングモデルに基づき，注目する骨梁表面要素 $c$ を中心とした 感知半径内の局所的な応力不均一性に応じた関数である骨 梁再構築駆動力 $\Gamma_{c}$ を

$$
\Gamma_{c}=\ln \left(\sigma_{c} \sum_{i}^{N} w\left(l_{i}^{c}\right) / \sum_{i}^{N} w\left(l_{i}^{c}\right) \sigma_{i}\right)
$$

として定義する.ここで, $\sigma_{i}$ は要素 $i$ に作用する相当応力値, $l_{i}^{c}$ は要素 $c$ と要素 $i$ の距離, $N$ は感知半径内に存在する骨梁 要素の総数である. また, $w\left(l_{i}^{c}\right)$ は距離に依存する重みである.
駆動力 $\Gamma_{c}$ 用いて，骨形成/吸収生起確率を定義した (Fig.1(a)). 低ひずみ範囲 $\left(\varepsilon_{c}<\varepsilon_{d u}\right)$ に相当する低いひずみ域 DW にある 骨梁表面要素においては, 骨細胞アポトーシスにより周囲の ひずみ分布にかかわらず，リモデリング回転によって吸収が 生じると仮定し，作用するひずみの值が低下するにつれてリ モデリング回転の活性化頻度が上昇し，その結果として骨吸 収が元進するとした. 高ひずみ範囲 $\left(\varepsilon_{o}<\varepsilon_{c}\right)$ である OW は，夕 一ゲットリモデリングにより周囲のひずみ分布にかかわら ず，リモデリング回転によって形成が生じると仮定する．ま た，作用するひずみの值が増加するにつれてリモデリング回 転の活性化頻度が上昇し，その結果として骨形成が六進する と想定した(Fig. 1(b)).

\section{2-2. 人工股関第手街解析モデル}

解析モデルとしては，個人ごとのモデル作成が容易である という理由から医療画像をべースとして作成されたものを 用いた. 人工股関節全置換術を受ける患者の CT 画像をべ一 スとして，専門医による手術計画における大腿骨形状，ステ ムサイズ，およびステムの位置を用いる. Slice 間隔およびピ クセルサイズは $0.7 \mathrm{~mm}$ であり，解像度は $512 \times 512$ の一般的 に臨床で使われている CT 画像である. 骨リモデリング解析 モデルとしては1pixel を 1 voxel 要素とした有限要素モデルと し, voxel 要素の増堿により骨構造変化を表した。 なお，骨 の最外郭とステムにおいては構造が変化しないよう設定し た。骨とステムのヤング率およびポアンン比はそれぞれ $20[\mathrm{GPa}]$ と $0.3,200[\mathrm{GPa}]$ と 0.4 と設定した.

荷重条件としては, 患者体重を参考とし大腿部に作用する カとモーメントのバランスにより, ステムにかかる荷重の大 きさおよび方向, 大腿骨大転子部で働く筋の合力および方向

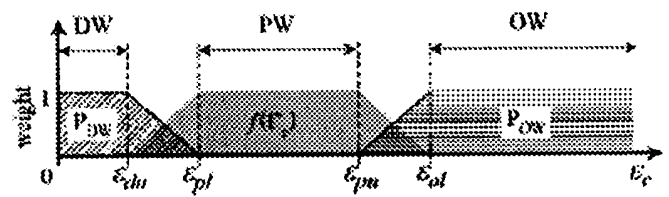

(ii) Intedrateit probatility of nentedeiting

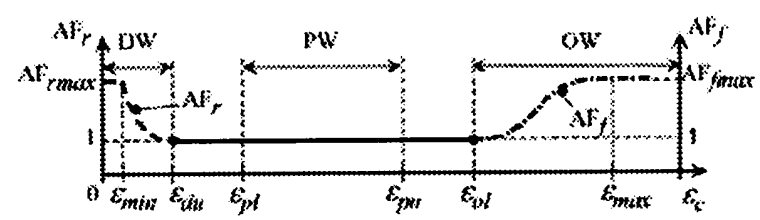

(b) Inckgaled renkeleling trapteney

Fig.1 Mathematical model for bone remodeling ${ }^{(5)}$ 

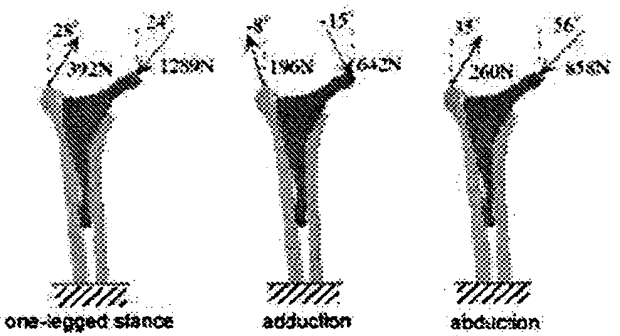

Fig.2 Boundary conditions.

を計算した。ここでの荷重を日常荷重として与えるため, Fig.2に示す姿勢ごと荷重を 3:1:1 の比率で与えることにした.

\section{3. 结果}

人工股関節術後の骨変化シミュレーションによる各 Gruen zone の骨部分の相当応力の平均值をシミュレーションのス テップごとに Fig. 3 に示す. 領域別ごとに異なる平均応力值 を示しており，遠位部 zone 3 および zone 5 と遠位に行くほど 平均応力值は高い. ステムのネック付近で低い応力值を示し ており，zone 7 で最も低い值を示している，各領域での平均 応力の初期值からの変化量を Fig. 4 に示す.他の領域に比へ， zone 7 および 1 で著しい変化を示している．これは， zone 1 および zone 7 では骨吸収が行われ，骨量が減少したことが原 因であると考えられる. 各領域での体積分率の変化を Fig. 5 に示す.各領域の体積分率の変化を見ても zone 1 および zone 7 での変化量が顕著であるため, この領域での力学負荷レ心゙ ルが低く，それにより骨吸収が行われていることが確認でき た.

\section{4. 考察}

骨リモデリングシミュレーションの結果と実際に人工股 関節全固換術を受けてから 10 年間の手術経過観察を行った 文献の結果と比較する. Herrera らは, 術後 10 年間測定され た骨密度を用い力学解析を行った結果を Gruen zone 別に平 均応力値とその変化量を示している(の). そこでは, 本シミュ レーションにより得られたのと同様の, zone 1 および zone 7 での平均応力值が低いこと,およびそれらの領域で応力変化 量が他の領域に比べ著しく高いという傾向が示されている. Herrera らの術後 400day までの急激な応力変化の様子は, シ ミュレーションでの 10 ステップまでの忘力変化と同様であ る.すなわち,このような結果は臨床で報告されている stress shieldingによる骨吸収が対応していると考えられる.しかし， 臨床での骨吸収傾向は, 術後 1500〜2000dayになると减少傾 向の変化がみられ，シミュレーションと異なる傾向を示して いる.このような臨床結果は骨組織が様々な影響因子を持っ ていることに対し, 力学的因子の影響に着目している本モデ ルのさらなる改変を示唆するものであると考えられる.

\section{5. まとめ}

本研究での力学環境下の骨りモデリングに基づく骨形態 変化シミュレーションは人工股関節手術後の長期的骨変化 をシミュレートすることができ, 臨床で観察される loosening 現象の特徴を再現することができた.これは, 本シミュレー ションモデルが人工関節の設計や術前計画を行う際に考虑

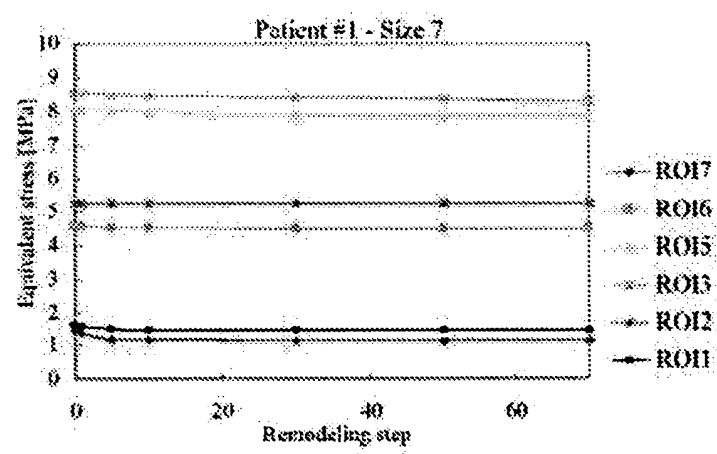

Fig. 3 Average equivalent stress versus trabecular bone remodeling simulation step for the femur with stem.

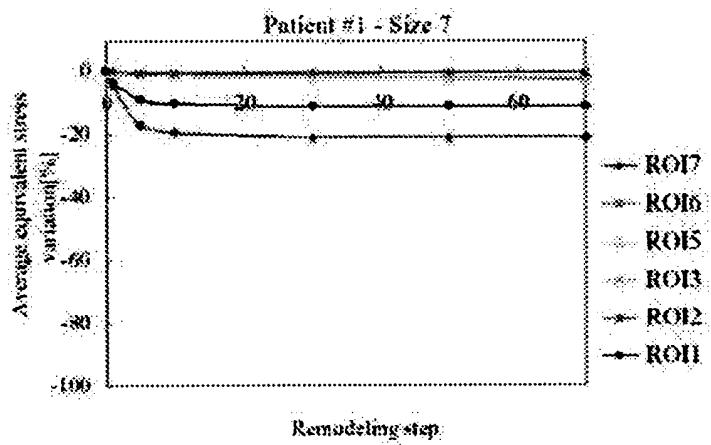

Fig. 4 Average equivalent stress variation versus trabecular bone remodeling simulation step for the femur with stem.

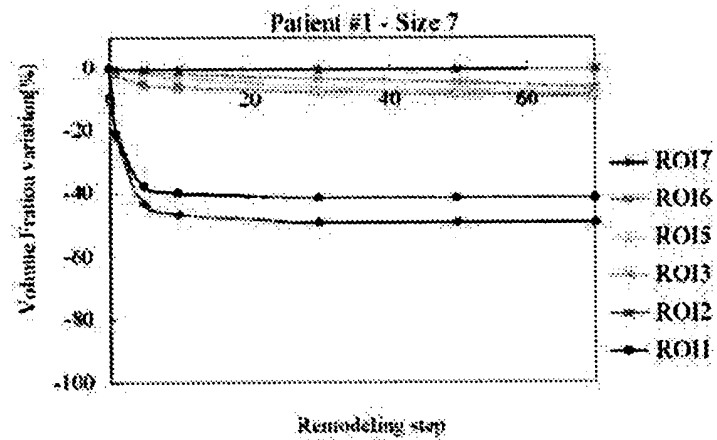

Fig. 5 Volume fraction variation versus trabecular bone remodeling simulation step for the femur with stem.

しなければならない骨変化を数值シミュレーションにより 予測する方法として利用しうる可能性を示唆しているもの といえる。

\section{参考文献}

(1)Jack, M.B., J. Arthroplasty, 11, No. 8 (1996), 905-915

(2)Makarand G. et al., J. Biomech., 33 (2000), 1655 1662

(3)Reggiani B. et al., J. Biomech., 40 (2007), 2252-2558

(4)Frost, H.M., Anat. Rec, 275 (2003), 1081-1101

(5)Kwon J.Y. et al., JBSE, 5(2010), 539-551

(6)Herrera A. et al., J. Biomech., 40 (2007), 3615-3625 